\title{
Toxicological Studies of Fruit Powder and Extracted Cake of Melia volkensii Guerke (Family: Meliaceae) on Maasai Goats in Kenya
}

\author{
Wanzala Wycliffe \\ Department of Biological Sciences, School of Science and Information Sciences, Maasai Mara University, Narok, Kenya
}

\section{Email address:}

osundwa1@yahoo.com

\author{
To cite this article: \\ Wanzala Wycliffe. Toxicological Studies of Fruit Powder and Extracted Cake of Melia volkensii Guerke (Family: Meliaceae) on Maasai \\ Goats in Kenya. International Journal of Pharmacy and Chemistry. Vol. 3, No. 6, 2017, pp. 82-85. doi: 10.11648/j.ijpc.20170306.13
}

Received: May 28, 2017; Accepted: October 8, 2017; Published: November 15, 2017

\begin{abstract}
Goat supplement feeds prepared from a dried Melia volkensii (Mv) fruit powder, which is known to contain insecticidal activity and the residual cake obtained after extracting oil from the fruit powder with aqueous ethanol, to remove the insecticidal activity do not adversely affect the growth and performance of Maasai goats even after exposure to the feed for two months. The feed prepared from the residual Mv cake was found to be more acceptable and palatable to the goats compared to the Mv powder, which was unextracted. Goats fed on the Mv residual cake also showed better performance than the controls fed on the wheat bran supplement or the ones fed on Mv powder. It is concluded from this study that Mv dry fruit powder and Mv extracted residual cake could be used as safe ruminant feed supplements in rural areas where M. volkensii is prominently on medicinal common use traditionally. The results also indicated that $\mathrm{Mv}$ is non-toxic to this ruminant mammalian model, hence environmentally safe for human use as insecticide with respect to a wide range of ethnic-based traditional claims. However, more in-depth scientific studies are necessary to generate sufficient data under different environmental conditions for comparative analysis and henceforth, considerations.
\end{abstract}

Keywords: Feed Supplement, Insecticide, Insect Growth Inhibitor, Maasai Goats, Melia volkensii

\section{Introduction}

Melia volkensii Guerke, 1895 (Family: Meliaceae) is a tropical tree found growing throughout the East African countries and native in Ethiopia, Kenya, Somalia and Tanzania $[1,2]$. The tree is deciduous, open crowned and laxly branched, ranging between 6 and $20 \mathrm{~m}$ tall when fully grown and mature. It is widely used in folk medicine for treatment of a number of diseases including pain relief [3] in a similar version, just like the Azadirachta indica A. Juss., 1830 (Neem), the popular medicinal plant native to India and the Indian subcontinent including Nepal, Pakistan, Bangladesh and Sri Lanka [4]. Extracts from milled whole dried fruits have been reported to contain a potent insect antifeedant activity against the desert locust, Schistocerca gregaria [5] and a growth inhibiting activity against mosquito larvae [6, 7]. More recently, the ethanol soluble fraction has been demonstrated to be effective in the field control of the desert locust $[8,9,10]$, thus raising the hope that Melia volkensii (Mv) could become a commercially feasible insecticide for locust control. The uses and applications of $M$. volkensii are on the increase and this therefore warrants more in-depth scientific and social studies on the plant in order to exhaust its potential value to humanity and further evaluate its environmental safety. The aim of this study therefore was to evaluate the Mv residual cake as a ruminant animal supplement feed as well as to attempt to detect any toxicological effects the Mv milled powder and extracted cake that they may have on the Maasai goat as a mammalian ruminant animal model since the goat is known to feed on the $M$. volkensii fruits in pasture.

\section{Materials and Methods}

Ripe fruits of $M$. volkensii were obtained from Embu, $150 \mathrm{~km}$ north of Nairobi, Kenya. The fruits were dried under shade and pulverised to a fine powder by means of a hammer-mill until the powder passed through a $1 \mathrm{~mm}$ mesh sieve. Part of the powder was extracted with $99 \%$ ethanol to exhaustion. The extracted 
Mv cake was then dried up in shade to constant weight. Wheat bran was obtained from an animal feeds store in Nairobi, Kenya.

The 15 six month old male castrated Maasai goats were purchased form a goat market in Nairobi, Kenya and kept in an animal house for one week to acclimatize. They were divided into 3 groups of 5 goats per group and one group of 5 goats was fed on purely wheat bran, another one was fed on Melia volkensii (Mv) fruit powder (unextracted), while the remaining group of 5 goats was fed on extracted Mv fruit powder (cake) for 56 days of the experiment. Due to bitter limonoids present in unextracted $M$. volkensii fruit powder, palatability of the Mv powder was improved by adding $10 \%$ of the wheat bran. All the groups of goats were uniformly supplemented with little hay, water and a $2 \mathrm{Kg}$ "cooper" salt licking brick. All experimental goats were fed Ad-libitum.

Each goat was weighted twice per week using a spring balance. The amount of feed per day per group was also recorded. All faecal pellets from each group were collected dried in the sun and weighed. After a period $f$ about two months, the goats were sacrificed and a postmortem carried out on the carcasses. The quality of the entire carcasses including visceral organs were assessed by a qualified and authorized veterinarian, Prof. Dr. Seth Marande Kisia and the meat given to human volunteers for consumption.

All the experiments were performed in compliance with the recommended guidelines and standards published by Kenya Veterinary Association (KVA) and Kenya Laboratory Animal Technician Association, Nairobi, Kenya.

\section{Results}

The results in Table 1 shows that on the average, each goat was able to take $3.4 \mathrm{~kg}$ of wheat bran per week, which is significantly higher than the amount of Mv powder (both unextracted and extracted - cake) consumed by the group, which received the powder $(\mathrm{P}<0.05)$. The weekly mean consumption of the $\mathrm{Mv}$ cake per goat was $2.2 \mathrm{~kg}$, which was somewhat between that observed for the other two groups. These values included the $10 \%$ amount of wheat bran added to improve the palatability of unextracted Melia volkensii fruit powder.

Table 2 shows that the total feacal output per goat for the last 56 days of the experiment was extremely low compared with the dry matter consumed in the groups that were fed on Mv powder (both unextracted and extracted - cake). The control group, which consumed the highest mean weight of dry supplement matter, produced the lowest feacal matter compared to the groups that were fed on Mv powder (both unextracted and extracted - cake). It was also observed that the group that fed on wheat bran produced soft feaces while the other two groups produced extremely solid, hard dry feacal pellets, occasionally having the texture of the compressed cake.

For the 8 weeks the experiment run, the mean body weight of the goats in the control group decreased steadily to the 5th week and then, started increasing steadily (Table 3). By the 8the week when the experiment was terminated however, the control goats had lost on the average, $2.4 \mathrm{~kg}$ which is $10.34 \%$ of the original weight. Similarly, the goats that fed on unextracted $\mathrm{Mv}$ powder lost $0.5 \mathrm{~kg}$ on the average for the 8 weeks of the experiment, which is $2.51 \%$ of the original mean weight (Table 3), with the lowest weight also being on week 5 . Table 3 also shows that those goats fed on the Mv cake steadily increased their weight from the first week to the 8th week, with an overall change of $1.38 \mathrm{~kg}$ mean weight increase. This increase in weight was $7.26 \%$ of the original mean weight.

Observations obtained during postmortem examinations and grading of the carcasses did not indicate any differences in all the three groups and no discernible lesions were apparent. The carcasses were lean in all cases with no significant adipose tissue deposits. Human volunteers who tasted the meat could not tell any difference in taste between the three groups.

At the end of the experiment goats form the three groups, i.e. control, those fed on $M$. volkensii unextracted fruit powder, and those fed on extracted fruit cake were all healthy and none showed any changes that could be associated with consumption of $M$. volkensii materials. All the goats were slaughtered and a postmortem examination carried on the carcasses. Apart from the presence of some hookworms in the intestines of a goat from the control group, this animal had injected mucous membranes. Two goats, one from the group that fed on unextracted fruit powder and another from the group that fed on the extracted cake had cysts, which were identified to be those of the tapeworm, Taenia hydatigena (Cysticercus tenciicollis) in the liver.

No other gross lesions were detected in any of the carcasses. The meat from the carcasses was passed as fit for human consumption on inspection and fed to volunteers. The quality of meat was the same for all groups and the human volunteers could not tell the difference between the flesh from the three groups.

Table 1. Weekly Consumption of Food Supplements (in Kg) by the Maasai Goats for Eight Weeks $(n=15)$.

\begin{tabular}{llll}
\hline \multirow{2}{*}{ Week } & \multicolumn{3}{l}{ Mean weight (Kg) consumption per goat per week } \\
\cline { 2 - 4 } & Control treatment (Fed on wheat bran) & Fed on unextracted Mv fruit powder & Fed on extracted Mv fruit powder (cake) \\
\hline 1 & 3.70 & 2.05 & 1.75 \\
2 & 3.35 & 2.20 & 1.10 \\
3 & 3.30 & 0.60 & 3.10 \\
4 & 2.20 & 0.65 & 2.10 \\
5 & 3.60 & 1.05 & 2.85 \\
6 & 4.25 & 1.30 & 1.75 \\
7 & 3.50 & 0.85 & 2.35 \\
8 & 3.15 & 0.70 & 2.55 \\
Mean weight $( \pm \mathrm{SE})$ & $3.40 \pm 28^{\mathrm{a}}$ & $1.2 \pm 02^{\mathrm{c}}$ & $2.20 \pm 12^{\mathrm{b}}$ \\
\hline
\end{tabular}

Note: Means capped by the same superscript alphabetical letters are not significantly different at $\leq 0.05$ (Student-Newman-Keuls test). 
Table 2. Mean Total Feacal Output (in Kg) Per Goat for 56 Days of the Experiment ( $n=15)$.

\begin{tabular}{ll}
\hline Type of treatment & Total average weight of feaces per goat for 56 days ( \pm SE) \\
\hline Control treatment (Fed on wheat bran) & $3.43 \pm 17^{\mathrm{c}}$ \\
Fed on unextracted Mv fruit powder & $4.88 \pm 09^{\mathrm{b}}$ \\
Fed on extracted Mv fruit powder (cake) & $5.85 \pm 27^{\mathrm{a}}$ \\
\hline
\end{tabular}

Note: Means capped by the same superscript alphabetical letters are not significantly different at $\leq 0.05$ (Student-Newman-Keuls test).

Table 3. Mean Weight ( \pm SE) (in Kg) of Maasai Goats Fed on Wheat Bran, Melia Volkensii (Mv) Fruit Powder and Extracted Mv Fruit Powder (Cake) for 56 Days of the Experiment $(n=15)$.

\begin{tabular}{llll}
\hline \multirow{2}{*}{ Week } & \multicolumn{3}{l}{ Mean weight $( \pm$ SE) of Maasai goats fed on different feeds for 56 days } \\
\cline { 2 - 4 } & $\begin{array}{l}\text { Control treatment (Fed on } \\
\text { wheat bran) }\end{array}$ & $\begin{array}{l}\text { Fed on unextracted Mv fruit } \\
\text { powder }\end{array}$ & $\begin{array}{l}\text { Fed on extracted Mv fruit } \\
\text { powder (cake) }\end{array}$ \\
\hline 0 & 23.2 & 19.9 & 19.0 \\
1 & (mean weight before start of experiment) & 20.4 & 19.5 \\
2 & 22.6 & 19.6 & 20.05 \\
3 & 22.05 & 19.1 & 20.3 \\
4 & 20.9 & 19.2 & 20.2 \\
5 & 19.15 & 18.6 & 20.4 \\
6 & 18.4 & 19.3 & 21.5 \\
7 & 19.8 & 19.4 & 21.3 \\
8 & 20.5 & 19.1 & 21.2 \\
Mean weight after 8 weeks & 20.2 & $19.4 \pm 0.17^{\mathrm{a}}$ & $20.38 \pm 0.28^{\mathrm{a}}$ \\
Change in mean weight after 8 weeks & $20.8 \pm 0.53^{\mathrm{a}}$ & -0.5 & +1.38 \\
\hline
\end{tabular}

Note: Means capped by the same superscript alphabetical letters are not significantly different at $\leq 0.05$ (Student-Newman-Keuls test).

\section{Discussion}

It is apparent that the control group of goats that fed on wheat bran consumed more food supplement compared to the experimental groups. It is therefore surprising that the weight of this particular group did not increase but instead showed a decrease, thus showing poor feed conversion ratio (FCR) [11]. It would appear therefore that under the animal house conditions, the combination of wheat bran and hay was not sufficient to provide adequate nutrition for weight gain [12]. It would appear on the other hand however that Mv extracted cake contains reasonable nutritional content to cause a reasonable weight increase in the eight weeks, thus showing good feed conversion ratio [13]. The Mv unextracted powder on the other hand was not consumed in large sufficient amounts to cause a considerable positive weight change due to the presence of bitter limonoids that spoiled the palatability of the food supplement [14]. Nonetheless, the bitter limonoids made the difference between palatability of extracted Mv fruit powder (cake) and unextracted Mv fruit powder to become obvious. In the course of the experiment, it was observed that the goats took a considerable time to start feeding on the unextracted Mv fruit powder while the group given access to the $\mathrm{Mv}$ extracted cake embarked on feeding on it immediately, with the same enthusiasm as those fed on wheat bran. The extra weight gained by the goats, which consumed the extracted Mv fruit powder (cake) could account for the difference between the weight gain in that group and that of the group fed on the unextracted Mv fruit powder. The unextracted Mv powder was bitter to the taste due to the presence of bitter limonoids and this accounts for its poor palatability albeit the presence of the required feed ingredients [14]. The extraction of $\mathrm{Mv}$ fruit powder with aqueous ethanol removed the bitter limonoid compounds, mainly the terpenoids and the oils, leaving the proteins still in the cake. Te cake therefore still retains the nutritional value that could account for the weight gain.

The survival of the group that fed on the unextrated $\mathrm{Mv}$ fruit powder and to a lesser extent that fed on the extracted Mv fruit powder (cake) was an indication that the active principles in Mv fruits was not acutely and even chronically toxic to the goats. The target receptors in insects which mediate the toxicity of $\mathrm{Mv}$ in insects may therefore be lacking in goats and, most likely in other mammals as well for it has been shown previously that Melia volkensii, which contains bitter limonoids related to azadiractins from Azadirachta indica, the crude $M$. volkensii fruit extract showed toxicity to a wide range of arthropods, particularly, insects including dipterans, lepidopterans and coleopterans [7, 15]. One is therefore tempted to conclude that $M$. volkensii fruit extract is safe to mammals including man and can safely be applied for insect control as an environmentally friendly and safe natural bioinsecticide [16, 17, 18, 19].

The relatively lower feacal output observed in the control group may indicate that they were consuming less hay compared to the other two experimental groups. Similarly, the high feacal output in the group that fed on the extracted Mv fruit powder (cake) could imply that the Mv cake may have stimulated these goats to feed more on hay. This difference may also explain the positive weight increase in this group.

\section{Conclusion}

In conclusion, I suggest that the extracted $\mathrm{Mv}$ fruit powder (cake) is a safe animal feed supplement that effects on mammals and therefore, the Mv extract could be taken as an 
environmentally safe insecticide [20], which has a higher safety margin than the common conventional insecticides for human use.

\section{Competing Interests}

I declare that there is no conflict of interests regarding the publication of this manuscript.

\section{Declaration}

I declare that this manuscript is my own original work, has not been presented for publication in any other Journal and that all sources of materials used for the research have been fully acknowledged accordingly.

\section{Acknowledgements}

The author wish to acknowledge the funding received from Deutsche Gesellschaftfür Technische Zusammenarbeit (German Technical Cooperation) (GTZ) for this particular project work on natural products through the combined efforts of assistance and coordination of Prof. Dr. Richard Warui Mwangi (now diseased) and Prof. Dr. Heinz Rembold. The author wish to thank the Technical Animal House Staff members of the defunct Zoology Department of the current, School of Biological Sciences, University of Nairobi for their professional management of goats in the animal house throughout the experimental period. I sincerely thank Prof. Dr. Seth Marande Kisia for helping in veterinary clinical studies of the project and meat inspection and examination during the slaughter period of the goats.

\section{References}

[1] Kamondo, B. M., Kimondo, J. M., Mulatya, J. M. and Muturi, G. M. (ed.), Recent Mukau (Melia volkensii, Gurke) Research and Development. Proceedings of the First National Workshop, KEFRI Kitui Regional Research Center. November 16 to 19, 2004.

[2] Orwa C., Mutua A., Kindt R., Jamnadass R., Anthony S., "Agroforestree Database: a tree reference and selection guide version 4.0."

http://www.worldagroforestry.org/sites/treedbs/treedatabases.a sp, as retrieved on Saturday, December 10th, 2016, 2:41 PM East Africa Time, 2009.

[3] Kokwaro J.O., "Medicinal plants of East Africa." University of Nairobi Press; Nairobi, Kenya, 3rd edition (December 29, 2009), pp. 534, 2009.

[4] Bhaskara M. V., Pramoda, S. J., Jeevikaa, M. U., Chandana, P K., Shetteppa, G., "Letters: MR Imaging Findings of Neem Oil poisoning". American Journal of Neuroradiology (American Society of Neuroradiology) 31: E60-E61, 2010.

[5] Mwangi R. W., "Locust antifeedant activity in fruits of Melia volkensii." Entomologia Experimentalis et Applicata, vol. 32, pp. 277-280, 1982.
[6] Mwangi, R. W., Mukiama T. K., "Evaluation of Melia volkensii extract fractions as mosquito larvicides." Journal of the American Mosquito Control Association, vol. 4, pp. 442447, 1988.

[7] Mwangi R. W., Rembold H., "Growth-inhibiting and larvicidal effects of Melia volkensii extracts on Aedes aegypti larvae." Entomologia Experimentalis et Applicata, vol. 46, pp. 103-108, 1988.

[8] Ashrafju, M., Ahmadi, K., Purhematy, A., "Impacts of Six Ethanolic Plant Extracts on Feeding and Developmental Time of Tetranychus urticae." Acta Phytopathologica et Entomologica Hungarica 49(2):245-251, 2014.

[9] Bashir Issa Abd-Elrazeg, Abdalla, "Effect of the Insects Growth Regulator Alsystin, on non-target Insects (Coleoptera, Tenebrionidae) in the Red Sea Coast of Sudan." PhD Thesis, University of Khartoum, 2015.

[10] Devappa, R. K., Makhar, H. P. S., Becker, K., “Jatropha toxicity- A review." Journal of toxicology and environmental health, 2010, Part B. 13: 476-507.

[11] Bodas, R., Manso, T., Mantecón, A. R., Juárez, M., De La Fuente, M. A., Gómez-Cortés, P., "Comparison of the fatty acid profiles in cheeses from ewes fed diets supplemented with different plant oils." Journal of Agricultural and Food Chemistry, 2010, 58:10493-10502.

[12] Van Beem D., Wellington D., Paganoni B. L., Vercoe P. E., Milton J. T. B., "Feed efficiency for meat and wool production by Merino and F1 Dohne $\times$ Merino lambs fed pelleted diets of different nutritive value." Australian Journal of Experimental Agriculture, 2008, 48, 879-884.

[13] Nudda, A., Battacone, G., Boaventura, N., Oscar, C., Antonello, F., Atzori, D. H. A., Alberto S., Pulina, G., "Feeding strategies to design the fatty acid profile of sheep milk and cheese." Revista Brasileira de Zootecnia, 2014, 43(8), 445-456.

[14] Tan Q-G., Luo X-D., "Meliaceous Limonoids: Chemistry and Biological Activities." Chemical Reviews, vol. 111, no. 11, pp. 7437-7522, 2011.

[15] Mwangi R. W., Rembold H., "Growth-regulating and larvicidal effects of Melia volkensii extracts on the larvae of Aedes aegypti." Entomologia Experimentalis et Applicata, vol. 46, pp. 103-108, 1987.

[16] Rajab M. S., Bentley M. D., "Tetranortriterpenes from Melia volkensii." Journal of Natural Products, vol. 551, pp. 840-844, 1988.

[17] Rajab M. S., Bentley M. D., Ashford A. R., Mendel M. J., “A new limonoid insect antifeedant from the fruit of Melia volkensii." Journal of Natural Products, vol. 551, pp. 168-171, 1988.

[18] Balan K., "Das Waschstum Der Gelbfiebermucke Naturstoffee Aus Melia volkensii." Ph. D. Thesis. University of Munchen, 1993.

[19] Ashrafju, M., Ahmadi, K., Purhematy, A., "Impacts of six ethanolic plant extracts on feeding and developmental time of Tetranychus urticae." Acta phytopathologica et entomologica Hungarica 2014 v. 49 no. 2 pp. 245-251.

[20] Hatem, A., Abdel-Samad, S., Soliman, M., Hussien, A., "Toxicologyical and physiological activity of plant extracts against Spodoptera littoralis (Boisduval) (Lepidoptera: Noctuidae) larvae.” Bol. San. Veg. Plagas, 2009, 35: 517-531. 